\title{
Pre-natal social stress and post-natal pain affect the developing pig reproductive axis
}

\author{
Cheryl J Ashworth ${ }^{1}$, Charis O Hogg ${ }^{1}$, Cindy W F Hoeks ${ }^{1,2}$, Ramona D Donald ${ }^{2}$, W Colin Duncan ${ }^{3}$, \\ Alistair B Lawrence ${ }^{2}$ and Kenny M D Rutherford ${ }^{2}$ \\ ${ }^{1}$ The Roslin Institute and R(D)SVS, University of Edinburgh, Easter Bush, Midlothian, EH25 9RG, UK, ${ }^{2} S A C$, Kings \\ Buildings, West Mains Road, Edinburgh, EH9 3JG, UK and ${ }^{3}$ Division of Reproduction and Development, Queen's \\ Medical Research Institute, University of Edinburgh, Little France, Edinburgh, EH16 4TJ, UK
}

Correspondence should be addressed to C J Ashworth; Email: cheryl.ashworth@roslin.ed.ac.uk

\begin{abstract}
This study assessed the effect of pre-natal social stress and post-natal pain on the reproductive development of young (approximately day 40) pigs. Male pigs carried by sows that were stressed by mixing with unfamiliar older sows for two 1-week periods during mid-pregnancy had lower plasma testosterone $(0.54 \mathrm{vs} 0.86 \mathrm{ng} / \mathrm{ml}$, s.E.D. $=0.11 ; P=0.014)$ and oestradiol $\left(E_{2} ; 22.9 \mathrm{vs} 38.7 \mathrm{pg} / \mathrm{ml}\right.$, S.E.D. $=7.80 ; \boldsymbol{P}=\mathbf{0 . 0 2 1})$ concentrations compared with males carried by unstressed control sows. Although there was no effect of pre-natal stress on female $E_{2}$ concentrations, female pigs carried by stressed sows had fewer primordial ovarian follicles (log $-4.32 / \mu \mathrm{m}^{2}$ vs $-4.00 / \mu \mathrm{m}^{2}$, S.E.D. $\left.=0.136 ; P=0.027\right)$. Tail amputation on day 3 after birth reduced $E_{2}$ concentrations in female $(4.78 \mathrm{vs} 6.84 \mathrm{pg} / \mathrm{ml}$, S.E.D. $=0.86 ; P=0.03)$ and in male $(25.6$ vs $34.9 \mathrm{pg} / \mathrm{ml}$, S.E.D. $=3.56 ; P=0.021)$ pigs and reduced both testis weight $(0.09 \%$ of body weight vs $0.10 \%$ of body weight, S.E.D. $=0.003 ; P=0.01)$ and the percentage of proliferating Leydig cells $(1.97$ vs 2.12, S.E.D. $=0.114 ;$ $\boldsymbol{P}=\mathbf{0 . 0 3 6})$ compared with sham-amputated littermate controls. There was a significant $(\boldsymbol{P}=\mathbf{0 . 0 3 6})$ interaction between the effects of pre-natal stress and post-natal pain on testicular expression of the steroidogenic enzyme 17 $\alpha$-hydroxylase, such that amputation increased expression in pigs born to control sows, but reduced expression in animals born to stressed sows. This study shows that stressful procedures associated with routine animal husbandry can disrupt the developing reproductive axis.

Reproduction (2011) 142 907-914
\end{abstract}

\section{Introduction}

It is widely recognised that the developing foetus and neonate is sensitive to changes in the external maternal environment, resulting in alterations in a range of physiological systems, including reproductive processes, in the foetus, neonate and resultant adult offspring (Ashworth et al. 2005). In livestock species, the majority of studies investigating the effects of pre- and early postnatal conditions on reproductive traits have focused on effects of altered maternal nutrition (typically under nutrition) during pregnancy and lactation. In sheep, for example, under nutrition during different stages of gestation reduced folliculogenesis in foetal ovaries (reviewed by Rhind (2004)), ovulation rates at first oestrus (Rae et al. 2002) and the number of Sertoli cells in the testes of male lambs (Bielli et al. 2002). A recent review highlighted that early post-natal life experiences are also important for lifetime fertility (Gardner et al. 2008). Less is known about the effects of other, non-nutritional, changes to the maternal environment on the developmental programming of the reproductive axis in livestock species.
Evidence from several mammalian species suggests that various forms of pre-natal stress (including social, spatial and environmental) affect the reproductive competence of offspring. For example, social stress evoked by short, frequent meetings of pregnant bank voles reduced the rate of offspring sexual maturation, uterine and testis weights and altered the attractiveness of adult offspring to the opposite sex (Marchlewska-Koj et al. 2003). Studies in which pregnant rats were stressed by several periods of restraint under intense light during the last week of pregnancy (Ward \& Weisz 1984) concluded, based on foetal plasma testosterone and progesterone concentrations, that the male foetal reproductive axis was more susceptible to pre-natal stress. Following this, many studies measured male offspring testosterone concentrations or the anogenital distance, which reflects the migration of the genital orifice towards the navel during foetal life and is often used as an indicator of masculinisation, as markers of pre-natal stress. Male guinea pigs born to mothers stressed by exposure to a strobe light during late pregnancy (Kapoor \& Matthews 2005) and male rats born to dams mixed with lactating rats during late 
pregnancy (P J Brunton, M V Donadio, S T Yao, M Greenwood, D Murphy \& J A Russell 2010, unpublished data) had lower plasma testosterone concentrations. However, Kattesh et al. (1979) reported no effects of stressing pregnant sows with heat and crowding for 50 days during mid-pregnancy on testosterone concentrations or libido of male offspring. Shorter anogenital distances in male offspring have been observed in prenatally stressed male rats (Williams et al. 1998, Mairesse et al. 2007) and in male pigs born to sows receiving weekly injections of ACTH during mid-pregnancy (Lay et al. 2008).

Many experimental situations used to create pre-natal stress do not reflect typical conditions that could be experienced by pregnant females. In pigs, EU legislation recommends that pregnant sows and gilts are housed in groups throughout pregnancy to ensure that their movement is not restricted and that animals can socially interact. However, as pigs form social dominance relationships, group housing with unfamiliar sows can be associated with aggressive interactions and social stress in subordinate animals (Jarvis et al. 2006). In addition, piglet's tails are often removed within a few days of life as a means to prevent later tail biting; a procedure which causes an acute stress response (Sutherland et al. 2008) and behaviour indicative of pain perception (Rutherford et al. 2009). Although there are apparently no reports of the effects of early post-natal pain or trauma on subsequent reproductive function, it is known that male pigs that were handled daily for the first 2 weeks of life had altered hypothalamic-pituitaryadrenal (HPA) function when assessed at 7 months of age (Weaver et al. 2000).

Our preliminary studies (Harker et al. 2008) which surveyed changes in a range of steroidogenic and gametogenic factors in pig ovaries and testes including aromatase, $3 \beta$-hydroxysteroid dehydrogenase, androgen receptor, LH receptor, STAR protein and VASA, indicated that testicular expression of the steroidogenic enzyme $17 \alpha$ hydroxylase $(17 \alpha-\mathrm{OH})$, which is involved in sexual development during foetal life, was affected by both prenatal stress and post-natal pain. The objectives of this study were to determine if the stress associated with routine

Table 1 Effect of mid-gestation stress on gestation length, litter size and piglet weight.

\begin{tabular}{lccc}
\hline & Control & Stressed & $\begin{array}{c}\text { Effect of } \\
\text { pre-natal } \\
\text { treatment }\end{array}$ \\
\hline Gestation length (days) & $115.3 \pm 0.59$ & $114.1 \pm 0.30$ & $\mathrm{NS}$ \\
Total litter size & $12.8 \pm 1.03$ & $13.4 \pm 0.53$ & $\mathrm{NS}$ \\
Number born alive & $12.8 \pm 1.00$ & $12.4 \pm 0.80$ & $\mathrm{NS}$ \\
Total litter weight (kg) & $16.0 \pm 1.08$ & $16.9 \pm 1.33$ & $\mathrm{NS}$ \\
Average litter weight $(\mathrm{kg})$ & $1.30 \pm 0.0498$ & $1.34 \pm 0.0834$ & $\mathrm{NS}$ \\
Within-litter standard & $0.05221 \pm 0.00654$ & $0.05359 \pm 0.00449$ & $\mathrm{NS}$ \\
$\quad$ error of birth weight & & & \\
\hline
\end{tabular}

Values are mean \pm S.E.M. NS, not significant.
Table 2 Weight $(\mathrm{kg})$ of the 64 pigs studied at birth and at slaughter.

\begin{tabular}{|c|c|c|c|c|c|}
\hline & & \multicolumn{2}{|c|}{ Control } & \multicolumn{2}{|c|}{ Stressed } \\
\hline & & Intact & Amputated & Intact & Amputated \\
\hline \multirow[t]{2}{*}{ Birth } & Female & $1.35 \pm 0.065$ & $1.34 \pm 0.078$ & $1.35 \pm 0.10$ & $1.37 \pm 0.10$ \\
\hline & Male & $1.34 \pm 0.036$ & $1.34 \pm 0.060$ & $1.38 \pm 0.11$ & $1.39 \pm 0.09$ \\
\hline \multirow[t]{2}{*}{ Slaughter } & Female & $10.9 \pm 0.76$ & $11.7 \pm 0.63$ & $11.5 \pm 0.27$ & $11.5 \pm 0.64$ \\
\hline & Male & $11.4 \pm 0.63$ & $11.7 \pm 0.59$ & $12.1 \pm 0.51$ & $12.0 \pm 0.75$ \\
\hline
\end{tabular}

Values are mean \pm S.E.M. There were no significant treatment effects or sex differences.

animal husbandry practices could affect the normal pattern of development of the reproductive axis and whether gender differences in the sensitivity to such stressors exist.

\section{Results}

There was no effect of pre-natal treatment on gestation length, litter size, piglet weight at birth or the withinlitter variability in piglet birth weight (Table 1). There was no effect of the pre- or post-natal treatment on weight at slaughter in male or female pigs (Table 2).

\section{Female pigs}

The number of each category of ovarian follicle observed is shown in Table 3. No antral follicles were present. Primordial follicles were the most prevalent follicle type. Female pigs born to sows that were stressed during pregnancy had fewer primordial follicles than those born to control sows (Table 3). Plasma oestradiol $\left(E_{2}\right)$ concentrations were lower in female pigs that had their tails amputated soon after birth (Table 3 ). There were no significant pre-natal stress $\times$ post-natal pain interactions on any of the traits measured in female pigs.

\section{Male pigs}

Testes collected from pigs that had their tails amputated soon after birth were lighter than those collected from intact pigs ( $P=0.01$; Table 4 ). Male pigs born to stressed sows had lower plasma testosterone and $E_{2}$ concentrations. $E_{2}$ concentrations were also lower in male pigs that had their tails amputated (Table 4). There was a significant interaction between the effects of pre-natal stress and post-natal pain on testicular expression of $17 \alpha-\mathrm{OH}$, such that amputation increased expression in pigs born to control sows, but reduced expression in animals born to stressed sows (Table 4).

A representative stained image of a testis section is shown in Fig. 1. There were no effects of pre-natal stress or post-natal pain the number of germ cells, seminiferous tubules, Leydig cells or Sertoli cells, when expressed either per total area of testis tissue (Table 5) or as a percentage of the total cells. However, the number and percentage of Leydig cells positively stained for Ki-67 
Table 3 Effect of pre-natal stress and post-natal pain on ovarian follicle development and plasma oestradiol $\left(\mathrm{E}_{2}\right)$ concentrations in female pigs.

\begin{tabular}{|c|c|c|c|c|c|c|c|}
\hline & \multicolumn{2}{|c|}{ Control } & \multicolumn{2}{|c|}{ Stressed } & \multirow[b]{2}{*}{ S.E.D. } & \multicolumn{2}{|c|}{$\boldsymbol{P}$} \\
\hline & Intact & Amputated & Intact & Amputated & & $\begin{array}{c}\text { Pre-natal } \\
\text { stress }\end{array}$ & Amputation \\
\hline Plasma $E_{2}(\mathrm{pg} / \mathrm{ml})$ & 7.05 & 4.28 & 6.72 & 5.21 & 0.86 & NS & 0.03 \\
\hline Primordial follicles $\left(\mathrm{no} . / \mu \mathrm{m}^{2}\right)^{\mathrm{a}}$ & -3.825 & -4.105 & -4.282 & -4.342 & 0.15 & 0.027 & NS \\
\hline Transitory follicles $\left(\right.$ no. $/ \mu^{2} \times 10^{-6}$ ) & 34.8 & 29.2 & 39.3 & 31.8 & 6.30 & NS & NS \\
\hline Primary follicles $\left(\right.$ no. $\left./ \mu \mathrm{m}^{2} \times 10^{-6}\right)$ & 8.402 & 12.288 & 12.134 & 9.144 & 3.65 & NS & NS \\
\hline Small preantral follicles $\left(\right.$ no. $/ \mu \mathrm{m}^{2} \times 10^{-6}$ ) & 8.135 & 6.855 & 4.746 & 6.886 & 1.69 & NS & NS \\
\hline Large preantral follicles $\left(\right.$ no. $/ \mu \mathrm{m}^{2} \times 10^{-6}$ ) & 1.432 & 1.967 & 2.807 & 1.534 & 1.19 & NS & NS \\
\hline Germ cell nests $\left(\right.$ no. $\left./ \mu \mathrm{m}^{2} \times 10^{-6}\right)$ & 3.187 & 0.431 & 2.726 & 0.499 & 1.81 & NS & $\begin{array}{c}\mathrm{NS} \\
(P=0.069)\end{array}$ \\
\hline
\end{tabular}

${ }^{\mathrm{a}}$ Data are log transformed. NS, not significant. S.E.D., standard error of the difference.

was lower in pigs that had their tails amputated. There were no significant effects of the interaction between pre-natal stress and post-natal pain on any measure of testis cell type.

\section{Discussion}

This study has shown that pre- and post-natal stresses associated with routine animal husbandry practices alter reproductive development of male and female pigs. In particular, circulating concentrations of testosterone and $E_{2}$ were lower in males born to stressed sows, while tail amputation soon after birth reduced $E_{2}$ concentrations in male and female pigs, testis weight and the percentage of proliferating Leydig cells. This is believed to be the first report showing that procedures conducted during the first few days of life affect reproductive development.

The results from this study suggest that, as with the rat (Ward \& Weisz 1984), testicular, but not ovarian, steroidogenesis is affected by pre-natal stress. In male pigs $E_{2}$ is synthesised in the Leydig cells of the foetal and post-natal testis (Wagner \& Claus 2008) and, unlike many other species, male pigs often have higher $E_{2}$ concentrations than females. In boars, $E_{2}$ acts with androgens to regulate sexual behaviour, anabolic metabolism and accessory gland function. The concentrations of $E_{2}$ in male pigs observed in this study are similar to those previously reported in young boars of the same age (Wagner \& Claus 2008).

The mechanisms by which pre-natal stress reduces post-natal testosterone and $E_{2}$ concentrations in male pigs are not known, particularly given the absence of pre-natal treatment effects on Leydig cell numbers. Previous studies using the same experimental paradigm have shown that mixed sows have elevated cortisol concentrations for up to 2 days after mixing (Jarvis et al. 2006, Rutherford et al. 2009); however, it is not known how long such elevated concentrations would persist. Pregnant rats that were stressed by restraint and bright lighting during the last 11 days of gestation had reduced placental expression of $11 \beta$-hydroxysteroid dehydrogenase (Mairesse et al. 2007), an enzyme that protects the foetus from high maternal cortisol concentrations. Based on these findings, it is reasonable to assume that foetuses carried by stressed sows would have elevated circulating cortisol concentrations which would provide increased negative feedback to the foetal hypothalamus and anterior pituitary, leading to a re-setting of the foetal HPA axis. It is possible that the stress-induced attenuation of the foetal HPA axis proposed by Mairesse et al. (2007) could also affect the foetal hypothalamicpituitary-gonadal axis. In support of this, male foetuses carried by stressed pregnant rats failed to show the surge of testosterone normally seen on days 18 and 19 (Ward \& Weisz 1984) and had lighter testes on day 21 of foetal life (Mairesse et al. 2007), suggesting a stress-induced depression in early testicular steroidogenesis. The sex difference in the steroidogenic response to pre-natal stress observed in this study could reflect the fact that foetal pig testes (Colenbrander et al. 1979), but not ovaries (Colenbrander et al. 1983) require continued pituitary support throughout pregnancy and would therefore be more susceptible to changes in hypothalamic-pituitary activity. In addition, the timing of

Table 4 Effect of pre-natal stress and post-natal pain on testis weight and plasma testosterone and oestradiol $\left(\mathrm{E}_{2}\right)$ concentrations in male pigs.

\begin{tabular}{|c|c|c|c|c|c|c|c|c|}
\hline & \multicolumn{2}{|c|}{ Control } & \multicolumn{2}{|c|}{ Stressed } & \multirow[b]{2}{*}{ S.E.D. } & \multicolumn{3}{|c|}{$\boldsymbol{P}$} \\
\hline & Intact & Amputated & Intact & Amputated & & Stress & Amputation & Interaction \\
\hline Combined testes weight (g) & 12.8 & 11.9 & 11.8 & 9.93 & 0.61 & NS & 0.045 & NS \\
\hline Combined testes weight as $\%$ body weight & 0.107 & 0.098 & 0.097 & 0.084 & 0.003 & NS & 0.01 & NS \\
\hline Testosterone concentrations $(\mathrm{ng} / \mathrm{ml})$ & 1.063 & 0.650 & 0.577 & 0.507 & 0.226 & 0.014 & NS & NS \\
\hline$E_{2}$ concentrations $(\mathrm{pg} / \mathrm{ml})$ & 45.8 & 31.6 & 25.4 & 20.4 & 8.57 & 0.015 & 0.021 & NS \\
\hline $17 \alpha$-Hydroxylase mRNA expression ${ }^{a}$ & 0.674 & 0.617 & 0.607 & 0.682 & 0.05 & NS & NS & 0.036 \\
\hline
\end{tabular}

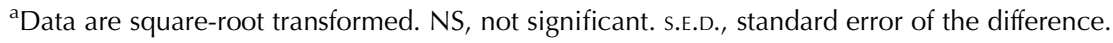




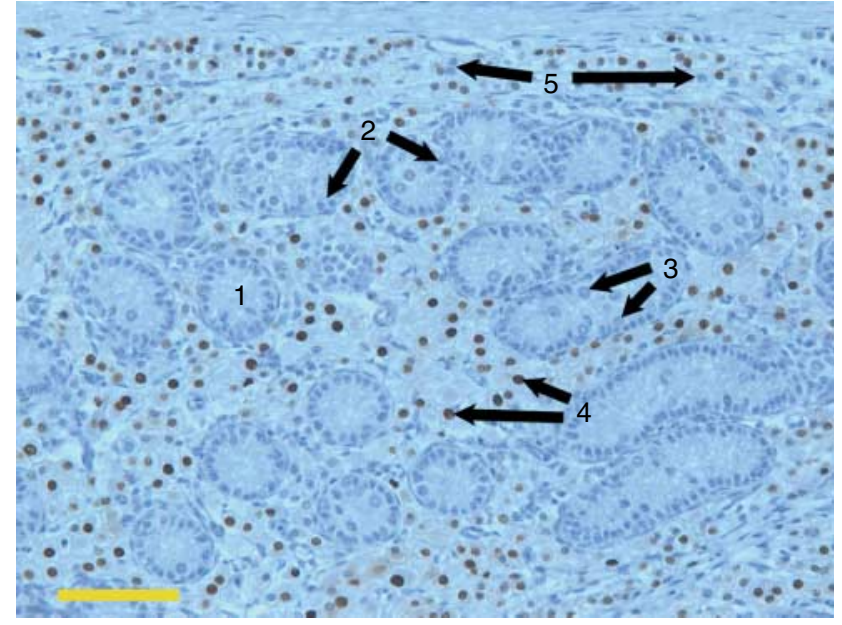

Figure 1 Representative section of day 40 pig testis showing cell types counted and Ki-67 immunostaining. Stained structures indicated by arrows are: seminiferous tubules (1), Sertoli cells (2), Germ cells (3), Leydig cells stained positive for Ki-67 (4), and Leydig cells stained negative for Ki-67 (5). Scale bar $=200 \mu \mathrm{m}$.

pre-natal stress coincides with waves of Leydig cell differentiation in male foetuses, but precedes the formation of primary and secondary ovarian follicles (Oxender et al. 1979).

It is possible that the differences in plasma $E_{2}$ and testosterone concentrations observed reflect differences in adrenal, rather than gonadal, steroid production. In what appears to be the only published study describing adrenal steroid secretion in young pigs, Holzbauer \& Newport (1969) suggested that androgens and progesterone-related compounds could account for up to $30 \%$ of total adrenal steroid secretion in 8 - to 12 -weekold female pigs. These authors presented some evidence that adrenal gland secretion of pregnenolone and $11 \beta-\mathrm{OH}$-androstenedione increased under stressful conditions, suggesting that altered adrenal production of $E_{2}$ or testosterone is unlikely to explain the lower concentrations of these steroids observed in this study. Furthermore, the observation that daughters of stressed sows have higher cortisol concentrations when measured on day 67 of life (Jarvis et al. 2006) would not suggest suppressed adrenal steroidogenesis is this group.
Other potential mechanisms should be considered. For example, observations that administration of naltrexone to stressed pregnant rats blocks the feminising effects of pre-natal stress on male offspring (Keshet \& Weinstock 1995, Reznikov et al. 2005), led to the proposal that the opioid system may be involved in mediating the effects of stress on the reproductive axis.

An intriguing finding from this study is that, regardless of pre-natal treatment, husbandry procedures conducted soon after birth affected reproductive development in both sexes. The observation that tail-amputated male pigs had fewer proliferating Leydig cells, smaller testes and lower $E_{2}$ concentrations suggests that testicular growth and development were compromised. As both the amputated and intact groups were handled in the same way and were of equivalent weight at slaughter, the results do not appear to be a consequence of the handling stress described by Weaver et al. (2000) or of altered feed intake. However, work by Klemcke et al. (1995) showing that neonatal (12 days of age) boars had increased ACTH and cortisol responses on the day after being restrained for $1 \mathrm{~min}$ highlights the extreme sensitivity of neonatal pigs to a modest stressor. Assessment of nociceptive functioning in siblings of the study animals used here (Sandercock et al. 2011) did not find any evidence of alterations as a consequence of tail docking, so the changes to reproductive function cannot be attributed to ongoing chronic pain, or more general alterations in nociceptive threshold.

In the light of recent work showing that pre-natal stress heightens piglet response to painful procedures (Rutherford et al. 2009), we hypothesised that reproductive consequences of tail amputation may also be influenced by whether the pig had been exposed to pre-natal stress. The only variable measured where there was a significant pre- by post-natal treatment interaction was in the testis expression of $17 \alpha-\mathrm{OH}$, such that amputation increased expression in pigs born to control sows, but reduced expression in animals born to stressed sows. This enzyme, which catalyses the production of precursors for glucocorticoid, oestrogen and androgen synthesis is involved in sexual development during foetal life and at puberty. Increased exposure to oestrogen during mid to

Table 5 Effect of pre-natal stress and post-natal pain on the number of testis cell types and the proliferative activity of Leydig cells in male pigs.

\begin{tabular}{|c|c|c|c|c|c|c|c|}
\hline & \multicolumn{2}{|c|}{ Control } & \multicolumn{2}{|c|}{ Stressed } & \multirow[b]{2}{*}{ S.E.D. } & \multicolumn{2}{|c|}{$\boldsymbol{P}$} \\
\hline & Intact & Amputated & Intact & Amputated & & $\begin{array}{l}\text { Pre-natal } \\
\text { stress }\end{array}$ & Amputation \\
\hline Germ cells $/ \mathrm{mm}^{2 \mathrm{a}}$ & 0.244 & 0.246 & 0.273 & 0.221 & 0.031 & NS & NS \\
\hline Seminiferous tubules $/ \mathrm{mm}^{2}$ & 0.112 & 0.127 & 0.125 & 0.128 & 0.011 & NS & NS \\
\hline Sertoli cells $/ \mathrm{mm}^{2}$ & 4.53 & 5.01 & 4.84 & 4.90 & 0.48 & NS & NS \\
\hline Leydig cells $/ \mathrm{mm}^{2}$ & 2.728 & 2.545 & 3.112 & 3.317 & 0.34 & $\begin{array}{c}\text { NS } \\
0.085\end{array}$ & NS \\
\hline Seminiferous tubules as proportion of total area & 0.328 & 0.375 & 0.350 & 0.3410 & 0.027 & NS & NS \\
\hline$\%$ Ki-67 positive Leydig cells ${ }^{b}$ & 2.133 & 2.031 & 2.114 & 1.917 & 0.114 & NS & 0.036 \\
\hline
\end{tabular}

${ }^{a}$ Data are square root transformed. ${ }^{b}$ Data are log transformed. NS, not significant. S.E.D., standard error of the difference. 
late pregnancy in the rat increased foetal Leydig expression of $17 \alpha-\mathrm{OH}$ (Majdic et al. 1996), indicating that external stressors can affect foetal steroid synthesis.

Given that the results described in this study were obtained from animals at a single pre-pubertal time point, it is not possible to say whether the treatment effects observed would be likely to persist into adult life or whether the lower hormone concentrations and cell numbers reflect developmental delay. Recent data from studies of reproductive aging (menopause) in women indicate that reproductive traits in pre-pubertal females can predict later reproductive capability. Menopause occurs when primordial ovarian follicles are depleted, despite the continued presence of a pool of later developing follicles (Appt et al. 2010). The number of primordial follicles between birth and puberty determines not only the total ovarian reserve, but also the rate at which primordial follicles are recruited into the pool of growing follicles. The number of follicles recruited is inversely related to the number of nongrowing (largely primordial) follicles (Hansen et al. 2008) such that females with fewer primordial follicles before puberty would be expected to reach reproductive senescence earlier. The relationship between the number of primordial ovarian follicles and reproductive aging in livestock species has not been studied. Given that lifetime reproductive performance of breeding females and the testosterone-driven growth potential of intact males are important traits for the pig industry, the relationships between early life experiences and commercially relevant reproductive traits warrant further study.

\section{Materials and Methods}

\section{Experimental animals}

In this study, 64 39- to 43-day-old pigs were used. These pigs were born to 16 Large White-Landrace primiparous sows that had either been stressed ( $S, n=8$ sows) by mixing with unfamiliar older sows for two 1-week periods during midpregnancy, or not (control, C, $n=8$ sows). Before insemination and through to mid-pregnancy sows remained in socially stable social groups of five or six animals. Two or three sows from each group were pre-allocated to the social stress treatment. The remaining sows in each group were controls. Allocation to the $\mathrm{S}$ group was made on the basis of a dominance test conducted in the home pen before the mixing period, and was balanced to ensure equal proportions of dominant, intermediate and subordinate animals in $\mathrm{S}$ and $\mathrm{C}$ groups. Oestrous cycles were not synchronised in study animals so on the first mix day $\mathrm{S}$ animals were on average on day 47 of gestation (range: 44-50). On the first day of mixing, sows allocated to the stress group were moved to a different pen containing three larger multiparous sows, where they were kept for 1 week, before being returned to their home pen. After 1 week in the home pen $\mathrm{S}$ sows were mixed again, with a different batch of sows, for one further week. Over this whole period control sows were left undisturbed in their home pen. Following the second mix period, all sows were left undisturbed in their original social group until being moved to standard farrowing crates 5 days before expected parturition around 114 days after insemination. Litter size and individual piglet birth weight was recorded.

On day 3 after birth half the female piglets and half the male piglets in each litter had their tails amputated (A) using a pair of surgical cutters. The remaining piglets were sham operated but remained intact (I). Piglets were weaned at around 28 days (mean \pm s.D. $=28 \pm 2.7$; no difference between $S$ and $C$ groups) and housed in their litter groups in straw-bedded pens. On days 39-43 of age four pigs from each litter, representing each gender and post-natal treatment combination (male I and A, female $I$ and $A$ ) were weighed and sedated with an i.m. injection of $2 \mathrm{mg} / \mathrm{kg}$ azaperone (Stresnil; Janssen Animal Health, High Wycombe, Buckinghamshire, UK) mixed with $5 \mathrm{mg} / \mathrm{kg}$ ketamine (Vetalar; Boehringer Ingelheim, Bracknell, Berkshire, UK). Once sedated, each pig received an intracardiac injection of $15 \mathrm{ml}$ of sodium pentobarbital (Euthatal; Merial Animal Health, Harlow, Essex, UK) to ensure rapid death. Immediately after death, the pig was exsanguinated and $\sim 10 \mathrm{ml}$ of whole blood collected. Both gonads were removed from each pig and the testes weighed. One testis from each male pig was cut into four roughly equivalent transverse sections, and one ovary from each female was bisected longitudinally. These tissue pieces were placed in Bouin's solution (Sigma-Aldrich Ltd) at room temperature. Similarly dissected pieces of the remaining gonad were snap frozen in liquid nitrogen and stored at $-80^{\circ} \mathrm{C}$.

All experimental procedures were approved by the Scottish Agricultural College Animal Ethics Committee in accordance with the UK Animals (Scientific Procedures) Act, 1986.

\section{Histology of ovary and testes}

After $24 \mathrm{~h}$ the Bouin's solution was replaced with $70 \%$ ethanol and the fixed samples stored at room temperature to await further processing. Samples were transferred to histological cassettes, dehydrated and embedded in paraffin. Sections $(5 \mu \mathrm{m})$ were cut using a microtome and placed on a microscope slide.

Two slides from each ovary were stained with haematoxylin and eosin. Bright field pictures of one section on each slide were taken at four pre-determined positions at magnifications of $10 \times$ and $20 \times$ on a Leica DMRB microscope fitted with a digital camera and the images analysed using Image Software (http://rsb.info.nih.gov/ij/). The developmental stage of ovarian follicles with visible oocyte nuclei was classified as described by Lundy et al. (1999). This classification is based on the number and structure of granulosa cells surrounding the follicle, ranging from primordial follicles with one layer of flattened granulosa cells to small antral follicles with more than five complete layers of cuboidal granulosa cells with a fully formed antrum. Clusters of cells that were not individually surrounded by granulosa cells were classified as egg cell nests. The number of ovarian follicles in each category was expressed relative to the area of the field of view.

The nuclear protein $\mathrm{Ki}-67$ was detected in testis sections by immunohistochemistry as a marker of cell proliferation (Bullwinkel et al. 2006). Following dewaxing and antigen 
retrieval using $0.01 \mathrm{M}$ sodium citrate, endogenous peroxidase activity, endogenous protein-associated biotin and non-specific antibody binding sites were blocked by sequentially incubating slides with $3 \% \mathrm{H}_{2} \mathrm{O}_{2}$, Avidin $\mathrm{D}$ and biotin solution (Vector Laboratories, Peterborough, UK) and normal horse serum in 5\% BSA. Two slides from each gonad were incubated with mouse MAB to Ki-67 (Ab17106; Abcam; 1:25) and two with mouse $\operatorname{lgG}(2 \mu \mathrm{g} / \mathrm{ml})$ as the negative control. The slides were incubated overnight at $+4{ }^{\circ} \mathrm{C}$ in a humidified chamber followed by $60 \mathrm{~min}$ at room temperature with a biotinylated horse anti-mouse secondary antibody (Vector Laboratories). An avidin-biotin HRP complex (Vector Laboratories), which binds to the biotin-labelled antibody, was added and detected using the peroxidase substrate, diaminobenzidene (Vector Laboratories). Testes slides were counterstained with haematoxylin (VWR, Lutterworth, UK). Images from four pre-determined positions from each slide were captured at $10 \times$ magnification using a Nikon Optishot 2 microscope and analysed by ImageJ. The area of the field of view and the area of seminiferous tubules were determined. Numbers of germ cells, seminiferous tubules, Sertoli cells and Leydig cells were counted. The number of $\mathrm{Ki}-67$ positive and negative Leydig cells was counted. From these data the number of each testis cell type per square millimeter and the percentage of the total cells represented by each cell type were calculated, as were the number of Sertoli cells/seminiferous tubule.

\section{$E_{2}$ and testosterone assays}

Blood samples were centrifuged at $1500 \mathrm{~g}$ and $4{ }^{\circ} \mathrm{C}$ for $10 \mathrm{~min}$ and the plasma decanted and frozen at $-20{ }^{\circ} \mathrm{C}$ to await analysis. Testosterone and total unconjugated $\mathrm{E}_{2}$ concentrations were determined by RIA using 'coat-a-count' kits (Siemens Healthcare Diagnostics, Deerfield, IL, USA) as previously described in pig plasma (Andersson et al. 1998, Landerdijk et al. 2009). Serially diluted pig plasma samples gave results parallel to the standard curve. In addition, in-house standards of known steroid concentration assayed using the coat-a-count kit gave the expected concentrations. All samples from female pigs were analysed in one $E_{2}$ assay and those from male pigs in another. $E_{2}$ was extracted from plasma using diethyl ether. The mean extraction efficiency was $81.7 \%$. Individual samples were corrected for extraction efficiency.
The minimum detectable dose was $3 \mathrm{pg} / \mathrm{ml}$ and the mean interassay coefficient of variation using three quality control samples was $4.35 \%$. Testosterone concentrations in plasma samples from male animals were determined directly in a single RIA. The minimum detectable dose was $0.08 \mathrm{ng} / \mathrm{ml}$.

\section{Total RNA extraction and CDNA synthesis}

Approximately, $50 \mathrm{mg}$ of frozen testis tissue was homogenised in $1 \mathrm{ml}$ RNA-Bee (AMS Biotechnology, Abingdon, Oxford, UK), $0.2 \mathrm{ml}$ chloroform was added and the sample centrifuged at $12000 \mathrm{~g}$ for $15 \mathrm{~min}$ at $4{ }^{\circ} \mathrm{C}$. The aqueous layer was removed, an equal volume of $70 \%$ ethanol added and the sample transferred to an RNeasy Mini spin column (Qiagen) and the column processed according to the manufacturer's instructions. Extracted RNA was stored at $-80^{\circ} \mathrm{C}$. The concentration of RNA was determined spectrophotometrically (NanoDrop Thermo-Scientific, Wilmington, DE, USA). The quality of the RNA was determined on an Agilent Technologies Bioanalyser (Wokingham, Berkshire, UK). The average RNA integrity number was 9.6 (range: 8.9-10).

cDNA was prepared from duplicate samples containing $1 \mu \mathrm{g}$ of isolated RNA by RT using random primers (Promega) and Superscript III (Invitrogen) and stored at $-20^{\circ} \mathrm{C}$. Controls containing no DNA transcript or no Superscript III were used to test for reagent contamination and genomic DNA contamination.

\section{Relative expression of $17 \alpha-\mathrm{OH}$ in testis}

The relative expression of $17 \alpha-O H$ transcripts in testis tissue was measured by qPCR using Platinum SYBR Green SuperMix UTD (Invitrogen) in accordance with the MIQE guidelines (Bustin et al. 2009). Following screening of the nine genes identified by Nygard et al. (2007) as suitable reference genes for expression studies in pig tissues, geNorm was used to select the three most stable genes: HMBS, SDHA and YWHA2. The primer sequences of the four genes used are shown in Table 6.

Duplicate samples of both cDNA samples prepared from each testis were analysed. Serial dilutions of pooled cDNA ranging from 1:2 to 1:64 in nuclease-free water were used as standards. Duplicate cDNA samples from one of the two cDNA preparations/testis, standards and controls containing no cDNA

Table 6 Porcine-specific primer sequences for qPCR.

\begin{tabular}{|c|c|c|c|c|}
\hline Primer names & Sequence $\left(5^{\prime}-3^{\prime}\right)$ & Amplicon size (bp) & $\operatorname{Tm}\left({ }^{\circ} \mathrm{C}\right)$ & Accession numbers \\
\hline $17 \alpha-\mathrm{OH}$ & & 202 & & M63507 \\
\hline Forward & CTGTGGGCAAGGAAATTTTG & & & \\
\hline Reverse & АСТTTCTGCGTTCGTCTTGG & & & \\
\hline HMBS2 & & 83 & 58 & DQ845174 \\
\hline Forward & AGGATGGGCAACTCTACСТG & & & \\
\hline Reverse & GATGGTGGCCTGCATAGTCT & & & \\
\hline SDHA & & 141 & 58 & DQ845177 \\
\hline Forward & СТACAAGGGGCAGGTTCTGA & & & \\
\hline Reverse & CTACAAGGGGCAGGTTCTGA & & & \\
\hline YWHAZ & & 203 & 60 & DQ845179 \\
\hline Forward & TGATGATAAGAAAGGGATTGTGG & & & \\
\hline Reverse & GTTCAGCAATGGCTTCATCA & & & \\
\hline
\end{tabular}


were included on each plate. Each qRT-PCR well contained $12.5 \mu \mathrm{l}$ platinum SYBR Green qPCR supermix (Invitrogen), $0.1 \mu \mathrm{l}$ ROX reference dye, $0.2 \mu \mathrm{l}(5 \mu \mathrm{M})$ each of forward and reverse primer and $3.4 \mu \mathrm{l}$ nuclease-free water. Normalisation factors for the three reference genes were calculated using the geNorm applet for Microsoft Excel as described by Vandesompele et al. (2002). The mean slope and intercept for the $17 \alpha-\mathrm{OH}$ calibration curves were -3.363 and 15.47 threshold cycle $\left(C_{\mathrm{t}}\right)(\mathrm{dRn})$ respectively. The PCR efficiency was $98.3 \%$.

\section{Statistical analysis}

Testes weights were expressed as a percentage of pig weight at slaughter.

The effects of the pre- and post-natal treatment and their interaction were analysed by two-way ANOVA (Genstat Version 13.1 for Windows; VSN International Ltd, Oxford, UK). For any specific comparison $n=8$, but litter was always the unit of measurement. The litter term was blocked to allow comparisons between intact and amputated same-sex siblings. Age at slaughter was fitted as a covariate. To overcome scale effects some data were log (number of primordial ovarian follicles, \% Ki-67 positively stained Leydig cells and the area of seminiferous tubules) or square root (testes expression of $17 \alpha$ $\mathrm{OH}$ and number of germ cells in the testes) transformed before analysis. Differences were considered significant when $P<0.05$.

\section{Declaration of interest}

The authors declare that there is no conflict of interest that could be perceived as prejudicing the impartiality of the research reported.

\section{Funding}

The BBSRC Animal Welfare Programme and the Scottish Government (RERAD).

\section{Acknowledgements}

We thank Peter Finnie and his staff at the SAC Easter Howgate Piggery for care of the animals, Bob Fleming (Roslin Institute) for advice on histology and image analysis and Sheena Robson (SAC) for excellent technical input. Studies on ovarian histology were conducted by Rachna Narayanan as part of her MSc research.

\section{References}

Andersson H, Rydhmer L, Lundstrom K, Wallgren M, Andersson K \& Forsberg M 1998 Influence of artificial light regimens on sexual maturation and boar taint in entire male pigs. Animal Reproduction Science 51 31-43. (doi:10.1016/S0378-4320(98)00054-2)

Appt SE, Clarkson TB, Hoyer PB, Kock ND, Goode AK, May MC, Persyn JT, Vail NK, Ethun KF, Chen H et al. 2010 Experimental reduction of reduced ovarian reserve in a nonhuman primate model (Macca fascicularis). Comparative Medicine 60 380-388.
Ashworth CJ, McEvoy TG, Rooke JA \& Robinson JJ 2005 Nutritional programming of physiological systems throughout development. Trends in Developmental Biology 1 117-129.

Bielli A, Perez R, Pedrana G, Milton JTB, Lopez A, Blackberry MA, Duncombe G, Rodreguez-Martinez H \& Martin GB 2002 Low maternal nutrition during pregnancy reduces the number of Sertoli cells in the newborn lamb. Reproduction, Fertility, and Development 14 333-337. (doi:10.1071/RD02046)

Bullwinkel J, Baron-Luhr B, Ludemann A, Wohlenberg C, Gerdes J \& Scholzen T $2006 \mathrm{Ki}-67$ protein is associated with ribosomal RNA transcription in quiescent and proliferating cells. Journal of Cellular Physiology 206 624-635. (doi:10.1002/jcp.20494)

Bustin SA, Benes V, Garson JA, Hellemans J, Huggett J, Kubista M, Mueller R, Nolan T, Pfaffl MW, Shipley GL et al. 2009 The MIQE guidelines: minimum information for publication of real-time PCR experiments. Clinical Chemistry 55 611-622. (doi:10.1373/clinchem. 2008.112797)

Colenbrander B, Van Rossum-Kok CMJE, Van Staaten HWM \& Wensing CJG 1979 The effect of fetal decapitation on the testis and other endocrine organs in the pig. Biology of Reproduction 20 198-204. (doi:10.1095/biolreprod20.2.198)

Colenbrander B, Van Rossum-Kok CMJE, Oxender WD \& Wensing CJ 1983 Ovarian development in control and decapitated pig fetuses. Biology of Reproduction 20 198-204. (doi:10.1095/biolreprod20.2.198)

Gardner DS, Lea RG \& Sinclair KD 2008 Developmental programming of reproduction and fertility: what is the evidence? Animal 2 1128-1134. (doi:10.1017/S1751731108002607)

Hansen KR, Knowlton NS, Thyer AC, Charleston JS, Soules MR \& Klein NA 2008 A new model of reproductive aging: the decline in ovarian nongrowing follicle number from birth to menopause. Human Reproduction 23 699-708. (doi:10.1093/humrep/dem408)

Harker LE, Duncan WC, Rutherford K, Rooke JA, Lawrence AB \& Ashworth CJ 2008 Effect of early life stressors on reproductive capability in pigs. Proceedings of the Annual Meeting of the Society of Reproduction and Fertility, Edinburgh, UK. Abstract P63, pp 75.

Holzbauer M \& Newport HM 1969 Adrenal secretion rates and adrenal tissue concentrations of pregnenolone, progesterone, $11 \mathrm{\beta OH}$-androstenedione and some other steroids in young pigs and dogs. Journal of Physiology 200 821-848.

Jarvis S, Moinard C, Robson SK, Baxter E, Ormandy E, Douglas AJ, SeckI JR, Russell JA \& Lawrence AB 2006 Programming the offspring by prenatal social stress: neuroendocrine activity and behaviour. Hormones and Behavior 49 68-80. (doi:10.1016/j.yhbeh.2005.05.004)

Kapoor A \& Matthews SG 2005 Short periods of prenatal stress affect growth, behaviour and hypothalamo-pituitary-adrenal axis activity in male guinea pig offspring. Journal of Physiology 566 967-977. (doi:10. 1113/jphysiol.2005.090191)

Kattesh HG, Kornegay ET, Gwazdauskas FC, Knight JW \& Thomas HR 1979 Peripheral plasma testosterone concentration and sexual behaviour in young prenatally stressed boars. Theriogenology 12 289-305. (doi:10. 1016/S0093-691X(79)80009-6)

Keshet GI \& Weinstock M 1995 Maternal naltrexone prevents morphological and behavioral alterations induced in rats by prenatal stress. Pharmacology, Biochemistry, and Behavior 50 413-419. (doi:10.1016/ 0091-3057(94)00289-U)

Klemcke HG, Brown-Borg HM \& Borg KE 1995 Functioning of the porcine pituitary-adrenocortical axis during neonatal development. Biology of the Neonate 67 274-286. (doi:10.1159/000244175)

Landerdijk P, Dieleman SJ, van Dooremalen C, Foxcroft GR, Gerritsen R, Hazeleger W, Soede NM \& Kemp B 2009 LH and FSH secretion, follicle development and oestradiol in sows ovulating or failing to ovulate in an intermittent suckling regimen. Reproduction, Fertility, and Development 21 313-322. (doi:10.1071/RD06172)

Lay DC, Kattesh HG, Cunnick JE, Daniels MJ, McMunn KA, Toscano MJ \& Roberts MP 2008 Prenatal stress effects on pig development and response to weaning. Journal of Animal Science 86 1316-1324. (doi:10.2527/jas.2007-0812)

Lundy T, Smith P, O'Connell A, Hudson NL \& McNatty KP 1999 Populations of granulosa cells in small follicles of the sheep ovary. Journal of Reproduction and Fertility 115 251-262. (doi:10.1530/jrf.0.1150251)

Mairesse J, Lesage J, Breton C, Breant B, Hahn T, Darnaudery M, Dickson SL, Seckl J, Blondeau B, Vieau D et al. 2007 Maternal 
stress alters endocrine function of the feto-placental unit in rats. American Journal of Physiology. Endocrinology and Metabolism 292 E1526-E1533. (doi:10.1152/ajpendo.00574.2006)

Majdic G, Sharpe RM, O'Shaughnessey PJ \& Saunders PT 1996 Expression of cytochrome P450 17alpha-hydroxylase/C17-20 lysase in the fetal rat testis is reduced my maternal exposure to exogenous estrogens. Endocrinology 137 1063-1070. (doi:10.1210/en.137.3.1063)

Marchlewska-Koj A, Kruczek M, Kapusta J \& Pochron E 2003 Prenatal stress affects the rate of sexual maturation and attractiveness in bank voles. Physiology \& Behavior 79 305-310. (doi:10.1016/S00319384(03)00099-4)

Nygard AB, Jorgensen CB, Cirera S \& Fredholm M 2007 Selection of reference genes for gene expression studies in pig tissues using SYBR green qPCR. BMC Molecular Biology 8 67. (doi:10.1186/14712199-8-67)

Oxender WD, Colenbrander B, van deWiel DFM \& Wensing CJG 1979 Ovarian development in fetal and pubertal pigs. Biology of Reproduction 21 715-721. (doi:10.1095/biolreprod21.3.715)

Rae MT, Kyle CE, Miller DW, Hammond AJ, Brooks AN \& Rhind SM 2002 The effects of undernutrition, in utero, on reproductive function in adult male and female sheep. Animal Reproduction Science 72 63-71. (doi:10.1016/S0378-4320(02)00068-4)

Reznikov AG, Nosenko ND \& Tarasenko LV 2005 Opiods are responsible for neurochemical feminisation of the brain in prenatally stressed rats. Neuroendocrinology Letters 26 35-38.

Rhind SM 2004 Effects of maternal nutrition on fetal and neonatal reproductive development and function. Animal Reproduction Science 122 205-214.

Rutherford K, Robson S, Donald R, Jarvis S, Sandercock D, Scott M, Nolan A \& Lawrence AB 2009 Prenatal stress amplifies the immediate behavioural responses to acute pain in pigs. Biology Letters 5 452-454. (doi:10.1098/rsbl.2009.0175)
Sandercock DA, Gibson IF, Rutherford KMD, Donald RD, Lawrence AB, Brash HM, Scott EM \& Nolan AM 2011 The impact of prenatal stress on basal nociception and evoked responses to tail-docking and inflammatory challenge in juvenile pigs. Physiology \& Behavior 104 728-737. (doi:10.1016/j.physbeh.2011.07.018)

Sutherland MA, Bryer PJ, Krebs N \& McGlone JJ 2008 Tail docking in pigs: acute physiological and behavioural responses. Animal 2 292-297. (doi:10.1017/S1751731107001450)

Vandesompele J, de Preter K, Pattyn F, Poppe B, van Roy N, de Paepe A \& Speleman F 2002 Accurate normalization of real-time quantitative RT-PCR data by geometric averaging of multiple internal control genes. Genome Biology 3 RESEARCH0034. (doi:10.1186/gb-2002-3-7-research0034)

Wagner A \& Claus R 2008 Aromatase and 11 -hydroxysteroid dehydrogenase 2 localisation in the testes of pigs from birth to puberty linked to changes of hormone pattern and testicular morphology. Reproduction, Fertility, and Development 20 505-512. (doi:10.1071/RD07136)

Ward IL \& Weisz J 1984 Differential effects of maternal stress on circulating levels of corticosterone, progesterone, and testosterone in male and female rat fetuses and their mothers. Endocrinology 114 1635-1644. (doi:10.1210/endo-114-5-1635)

Weaver SA, Aherne FX, Meaney MJ, Schaefer AL \& Dixon WT 2000 Neonatal handling permanently alters hypothalamic-pituitary-adrenal axis function, behaviour and body weight in boars. Journal of Endocrinology 164 349-359. (doi:10.1677/joe.0.1640349)

Williams MT, Hennessy MB \& Davis HN 1998 Stress during pregnancy alters rat offspring morphology and ultrasonic vocalisations. Physiology \& Behavior 63 337-343. (doi:10.1016/S0031-9384(97)00428-9)

Received 3 August 2011

First decision 5 September 2011

Accepted 7 October 2011 